\title{
Jute Agro Textile as a Mulching Tool for Improving Yield of Green Gram
}

\author{
Anwesha Sarkar*, Sanjib Barui, P.K. Tarafdar and S.K. De \\ Department of Soil and Water Conservation, Bidhan Chandra Krishi Viswavidyalaya, \\ Mohanpur, Nadia-741252, West Bengal, India \\ *Corresponding author
}

\begin{abstract}
A B S T R A C T
\section{Keywords}

Crop yield, Green gram, Jute agro textile, Moisture use efficiency, Pre-kharif season

Article Info

Accepted:

26 April 2018

Available Online:

10 May 2018

The present research work has been carried out to understand the effect of different strength of jute agro textiles on yield and moisture use efficiency of green gram (Vigna radiata L.) grown for two successive years 2016 and 2017 during the pre-kharif season from last week of February to 2nd week of May at the farmer's field in the Kamalpur village, Chatna block, Bankura, West Bengal. The experiment was conducted with five treatments viz. $\mathrm{T}_{1}-1000 \mathrm{GSM}, \mathrm{T}_{2}-800 \mathrm{GSM}, \mathrm{T}_{3}-600 \mathrm{GSM}, \mathrm{T}_{4}-400 \mathrm{GSM}$ jute agro textiles and $T_{5}$ - farmer's practices where GSM $=\mathrm{g} / \mathrm{m}^{2}$. Results showed that, the yield is increased with each treatment, attaining the highest value of $6.74 \mathrm{q} / \mathrm{ha}$ in $\mathrm{T}_{1}$ which is 185.6 $\%$ more than control. The moisture use efficiency of the crop, was increased significantly by $70.27 \%$ (on an average) due to the treatments over control. Though the best results were obtained in $T_{1}$, but the increment occurred in a declining pattern from $T_{2}$ to $T_{1}$ i.e. further increase in strength after $T_{2}$ was not proved to be efficient.
\end{abstract}

\section{Introduction}

India is the largest producer and consumer of pulse in the world, accounting for 25 percent of global production and 15 percent consumption (Saraswati et al., 2004). Green gram (Vigna radiata L.) belongs to the family Leguminoceae and sub family Papilionaceae, is being grown as one of the principal pulse crop since ages in the country.

The annual world production area of mungbean is about 5.5 million hectare. India is the primary greengram producer and contributes about $75 \%$ of the world's production (Taunk et al., 2012). It is one of the major Kharif pulse crops in India covering
34.4 lakh hectare of area in the country with total production of 14 lakh tonnes and productivity of 415.70 kilogram per hectare (Anonymous, 2015). It is highly nutritious pulse crop having nearly 24 to $25 \%$ protein in seed.

To increase the production capacity of this highly protenaceous crop many agronomic measures are adopted among which mulching is proved to be more efficient. Mulching usually involves placing a layer of organic or inorganic material on the soil surface around the desired crop to modify the growing microenvironment for improving crop productivity. Materials such as wheat straw, rice straw or husk, grass, weeds, leaves, leaf mold, animal 
manures, compost, sawdust and woodchips are usually used as organic mulches and that of plastic or polyethylene film, sand, gravel, pebbles, etc. are used as inorganic mulches (Khurshid et al., 2006; Seyfi and Rashidi, 2007; Quilty and Cattle, 2011). Mulching with synthetic (polyethylene film) or organic (crop residue) materials has been widely practiced for production of commercial widely spaced crops and vegetables including tomato, lettuce and others (Albert et al., 2010). Geotextiles or agrotextiles mulches, permeable fabrics made from polypropylene or bio-degradable materials like jute and other fabrics, are most effective in modifying soil environment, suppressing weed and increasing crop yield (Manna et al., 2018). In this context, jute agro textile, made from $100 \%$ natural bust fibre has the same potential to improve crop yield as well as soil fertility and productivity status. Application of jute agro textile mulches increased the yield of capsicum and pointed gourd (Saha et al., 2006) and that of sweetlime and turmeric (Nag et al., 2008) compared to control where no mulching materials were used.

Most of the earlier researchers have studied the impact of various mulches and their many beneficial effects, but hardly anybody attempted to study the beneficial aspects of different strength of jute agro textiles specially in increasing yield of green gram and their moisture use efficiency on Alfisols of West Bengal, India where mean annual rainfall is less $(\sim 1250 \mathrm{~mm})$ and soil productivity is also less due to its light texture, acidic in nature, low fertility status and low water holding capacity.

On this background, a field experiment was undertaken to explore, in details, the effects of jute agrotextile mulches on growth and productivity of green gram (Vigna radiata L.) in Alfisols or lateritic soil of West Bengal, India.

\section{Materials and Methods}

\section{Experimental site}

The present study was carried out at the farmer's field in the Kamalpur village, Chatna block, Bankura, West Bengal under the soil order Alfisols, lies between 22.08' N L and 87.21 ' $\mathrm{E} \mathrm{L}$, the general elevation ranges from 200 to $500 \mathrm{~m}$ above mean sea level with the mean annual rainfall of $1247 \mathrm{~mm}$. The soils are characterized by slightly acidic, low clay and organic matter content and dominants by kaolinitic and illitic type of clay mineral with the presence of small modules of iron concretions which make it beyond the optimum productivity level (Fig. 1).

\section{Methodology}

The variety named sona moog of green gram was sown on last week of February of each consecutive years and grown during the prekharif or summer season of 2016 and 2017. Five treatments i.e. $\mathrm{T}_{1}-1000 \mathrm{GSM}, \mathrm{T}_{2}-800$ GSM, T $3^{-} 600$ GSM, T 4 - 400 GSM jute agro textiles and $\mathrm{T}_{5}$-farmer's practices (control) along with NPK dose of $20-40-20 \mathrm{~kg} / \mathrm{ha}$ were used for the production of green gram where GSM = gram per meter square. The area of each plot was 20 sq.m with spacing of $30 \mathrm{~cm}$ X $10 \mathrm{~cm}$. Before seeding @ $15 \mathrm{~kg} / \mathrm{ha}$, seed treatment was done by Rhizobium culture (1 pack/bigha) and with Diathem M-45 (3 $\mathrm{gm} / \mathrm{kg}$ ). The other recommended package of practices was adopted for growing the crop. Various strength of jute agro textiles were laid before sowing the crop. All the treatments were replicated four times in Randomized Block Design. All the yield attributes and physiological parameters were recorded and moisture use efficiency was calculated by the relationship as MUE $(\mathrm{kg} / \mathrm{mm} / \mathrm{ha})=$ Total yield $(\mathrm{kg} / \mathrm{ha}) /$ Total water use $(\mathrm{mm})$. The obtained data were subjected to statistical investigation following the analysis of variance techniques 
by using software packaging of MS Excel and OPSTAT. Statistical significance between means of individual treatments was assessed using Fisher's Least Significant Difference (LSD) at $1 \%$ level of probability (Gomez and Gomez. 1984).

\section{Results and Discussion}

\section{Yield and yield attributes}

The results of pooled data on yield and yield attributes of green gram grown in 2016 and 2017 during summer season with only one sprinkler irrigation during pod initiation on $1^{\text {st }}$ year and flowering initiation on $2^{\text {nd }}$ year showed variation with the application of various kinds of jute agro textiles (Table 1). The yields of green gram significantly increases with the application of each treatment and response over control were 4.38 q/ha (185.6\%), 3.76 q/ha (159.32\%), 2.48 q/ha $(105.08 \%)$ and 2.18 q/ha $(92.37 \%)$ respectively in 1000, 800, 600, 400 GSM jute agro textiles (Figure 2). Though the highest yield was observed in 1000 GSM but in case of percentage comparison between treatments 800 GSM showed more efficient result as $54.24 \%$ increment occurred in $\mathrm{T}_{2}$ from $\mathrm{T}_{3}$ than $\mathrm{T}_{1}$ from $\mathrm{T}_{2}(26.28 \%$ increment). Similarly the no. of pods per plant, no. of grains per pod and 1000 grain weight were also found highest in $\mathrm{T}_{1}$ compared to the other treatments. Result further reveals that green gram yield is positively and significantly correlated with number of pod/plant $(\mathrm{r}=0.960)$, number of grain/pod ( $\mathrm{r}=0.992), 1000$ grain weight $(\mathrm{r}=$ 0.932), water use efficiency $(r=0.996)$ and crop growth rate $(\mathrm{r}=0.951)$ at $1 \%$ level of significance (Table 4). The above findings were supported by Paza (2007).

\section{Physiological parameter of green gram}

The results of the number of branch/ plant, plant height, dry matter production and crop growth rate influencing yield and growth of green gram crop due to application of various JAT are presented in (Table 2). Plant height and no of branches per plant had increased upto $32.58 \mathrm{~cm}$ and 9.51 from $26.74 \mathrm{~cm}$ and 5.27 respectively. The results also found that response of dry matter production over control due to each treatment were $136.95 \mathrm{~g} / \mathrm{m}^{2}(39.59$ $\%), \quad 116.23 \mathrm{~g} / \mathrm{m}^{2} \quad(33.6 \%), \quad 49.79 \mathrm{~g} / \mathrm{m}^{2}$ (14.39\%), and $19.91 \mathrm{~g} / \mathrm{m}^{2}(5.75 \%)$ in $\mathrm{T}_{1}, \mathrm{~T}_{2}$, $\mathrm{T}_{3}, \mathrm{~T}_{4}$ respectively. The total dry matter weight of green gram significantly increased with the application of different types of JAT over control but response is highest in $\mathrm{T}_{2}$ from $\mathrm{T}_{3}(66.44 \%)$ than $\mathrm{T}_{1}$ from $\mathrm{T}_{2}(20.72 \%)$. The response of crop growth rate over control due to each treatment were $1.98 \mathrm{~g} / \mathrm{day} / \mathrm{m}^{2}$ $(37.85 \%), \quad 1.72 \mathrm{~g} / \mathrm{day} / \mathrm{m}^{2} \quad(32.88 \%), \quad 0.81$ $\mathrm{g} / \mathrm{day} / \mathrm{m}^{2}(15.48 \%)$, and $0.4 \mathrm{~g} / \mathrm{day} / \mathrm{m}^{2}(7.64 \%)$ $\mathrm{g} /$ day $/ \mathrm{m}^{2}$ in $\mathrm{T}_{1}, \mathrm{~T}_{2}, \mathrm{~T}_{3}, \mathrm{~T}_{4}$ respectively. Again the crop growth rate is found to be highest in $\mathrm{T}_{2}$ from $\mathrm{T}_{3}(17.4 \%)$ than $\mathrm{T}_{1}$ from $\mathrm{T}_{2}(4.97 \%)$. According to it, the best result is found in case of treatment 800 GSM as it shows a declining trend of increment after this treatment.

\section{Total water use and moisture use efficiency of green gram}

Periodical soil moisture content in percentage due to variations of different geotextile treatment in soils growing with green gram was monitored by weekly basis, the results of which are presented in figure 5. Consistent variations have been observed in the soil moisture content under different treatment. Highest moisture percentage was found in 1000 GSM and lowest values were found in the control plots The total moisture use by plant i.e. water use pattern are found to follow in the order: $\mathrm{T}_{1}(264.87 \mathrm{~mm})>\mathrm{T}_{2}(259.94$ $\mathrm{mm})>\mathrm{T}_{3}(250.7 \mathrm{~mm})>\mathrm{T}_{4}(248.01 \mathrm{~mm})>$ control (185.41 mm) (Table 3). The total water use by plant and yield were significantly and positively correlated and the $\mathrm{R}^{2}$ value is 0.882 according to linear trend line (Figure 4 ). 
Table.1 Effect of different jute agro textiles on yield and yield component of green gram. (Mean of two years)

\begin{tabular}{|c|c|c|c|c|}
\hline Treatments & $\begin{array}{c}\text { No. of pod/ } \\
\text { plant }\end{array}$ & No. of grain/pod & $\begin{array}{c}\text { 1000 Grain } \\
\text { weight }(\mathrm{g})\end{array}$ & Yield (Q/ha) \\
\hline $\mathrm{T}_{\mathbf{1}}-\mathbf{1 0 0 0}$ GSM & 38.25 & 9.59 & 37.20 & 6.74 \\
\hline $\mathrm{T}_{2}-\mathbf{8 0 0}$ GSM & 36.06 & 8.96 & 36.84 & 6.12 \\
\hline $\mathrm{T}_{3}-\mathbf{6 0 0}$ GSM & 34.13 & 7.81 & 35.35 & 4.84 \\
\hline $\mathrm{T}_{4}-\mathbf{4 0 0}$ GSM & 32.67 & 7.26 & 34.94 & 4.54 \\
\hline $\mathrm{T}_{5}-$ control & 28.68 & 5.84 & 26.78 & 2.36 \\
\hline SE $(\mathbf{m}) \pm$ & 0.019 & 0.15 & 0.028 & 0.008 \\
\hline C.D. at 5 \% & 0.064 & 0.496 & 0.091 & 0.025 \\
\hline
\end{tabular}

Table.2 Effect of different jute agro textiles on physiological parameters of green gram (Mean of two years)

\begin{tabular}{|c|c|c|c|c|}
\hline Treatments & No. of Branch & $\begin{array}{c}\text { Plant height } \\
(\mathrm{cm})\end{array}$ & $\begin{array}{c}\text { Dry matter } \\
\text { production } \\
\left(\mathrm{g} / \mathbf{m}^{2}\right)\end{array}$ & $\begin{array}{c}\text { Crop growth } \\
\text { rate }\left(\mathrm{g} / \mathrm{day} / \mathbf{m}^{2}\right)\end{array}$ \\
\hline $\mathrm{T}_{\mathbf{1}}-\mathbf{1 0 0 0}$ GSM & 9.51 & 32.58 & 482.87 & 7.21 \\
\hline $\mathrm{T}_{2}-\mathbf{8 0 0}$ GSM & 8.79 & 31.65 & 462.15 & 6.95 \\
\hline $\mathrm{T}_{3}-\mathbf{6 0 0}$ GSM & 7.66 & 29.77 & 395.71 & 6.04 \\
\hline $\mathrm{T}_{4}-\mathbf{4 0 0}$ GSM & 6.78 & 28.68 & 365.83 & 5.63 \\
\hline $\mathrm{T}_{5}-$ control & 5.27 & 26.74 & 345.92 & 5.23 \\
\hline SE $(\mathbf{m}) \pm$ & 0.006 & 0.011 & 1.577 & 0.007 \\
\hline C.D. at 5 \% & 0.019 & 0.038 & 5.224 & 0.023 \\
\hline
\end{tabular}

Table.3 Effect of different jute agro textiles on total water use and moisture use efficiency of green gram (Mean of two years)

\begin{tabular}{|c|}
\hline Treatments \\
\hline $\mathrm{T}_{1}-1000 \mathrm{GSM}$ \\
\hline $\mathrm{T}_{2}-800 \mathrm{GSM}$ \\
\hline $\mathrm{T}_{3}-600 \mathrm{GSM}$ \\
\hline $\mathrm{T}_{4}-400 \mathrm{GSM}$ \\
\hline $\mathrm{T}_{5}-$ control \\
\hline SE $(\mathrm{m}) \pm$ \\
\hline C.D. at $5 \%$ \\
\hline
\end{tabular}

Total Water Use (mm)
Moisture Use Efficiency ( $\mathrm{Kg} / \mathrm{ha}-\mathrm{mm})$

\begin{tabular}{|c|c|}
\hline 264.87 & 2.54 \\
\hline 259.94 & 2.35 \\
\hline 250.70 & 1.93 \\
\hline 248.01 & 1.83 \\
\hline 185.41 & 1.27 \\
\hline 0.77 & 0.006 \\
\hline 2.54 & 0.021 \\
\hline
\end{tabular}


Table.4 Correlation metrics involving yield and yield attributes characters of green gram (Mean of two years)

\begin{tabular}{|c|c|c|c|c|c|c|}
\hline Correlations & $\begin{array}{c}\text { No. of } \\
\text { pod/plant }\end{array}$ & $\begin{array}{c}\text { No. of } \\
\text { grain/po } \\
\text { d }\end{array}$ & $\begin{array}{c}1000 \\
\text { Grain } \\
\text { weight (g) }\end{array}$ & $\begin{array}{c}\text { WUE } \\
\text { (kg/ha- } \\
\text { mm) }\end{array}$ & $\begin{array}{c}\text { Crop } \\
\text { growth rate } \\
\text { (g/day/m2) }\end{array}$ & $\begin{array}{l}\text { Yield } \\
\text { (Q/ha) }\end{array}$ \\
\hline No. of pod/plant & 1 & & & & & \\
\hline No. of grain/pod & $0.950 * *$ & 1 & & & & \\
\hline $\begin{array}{l}1000 \text { Grain } \\
\text { weight(g) }\end{array}$ & $0.951 * *$ & $0.886 * *$ & 1 & & & \\
\hline $\begin{array}{l}\text { Water use efficiency } \\
\text { (kg/ha-mm) }\end{array}$ & $0.942 * *$ & $0.998 * *$ & $0.896 * *$ & 1 & & \\
\hline $\begin{array}{l}\text { Crop growth rate } \\
\text { (g/day/m2) }\end{array}$ & $0.899 * *$ & $0.978 * *$ & $0.789^{\mathrm{NS}}$ & $0.971 * *$ & 1 & \\
\hline Yield (Q/ha) & $0.960 * *$ & $0.992 * *$ & $0.932 * *$ & $0.996 * *$ & $0.951 * *$ & 1 \\
\hline
\end{tabular}

** Correlation is significant at the 0.01 level (2-tailed).

Fig.1 Field view of green gram growing in summer season

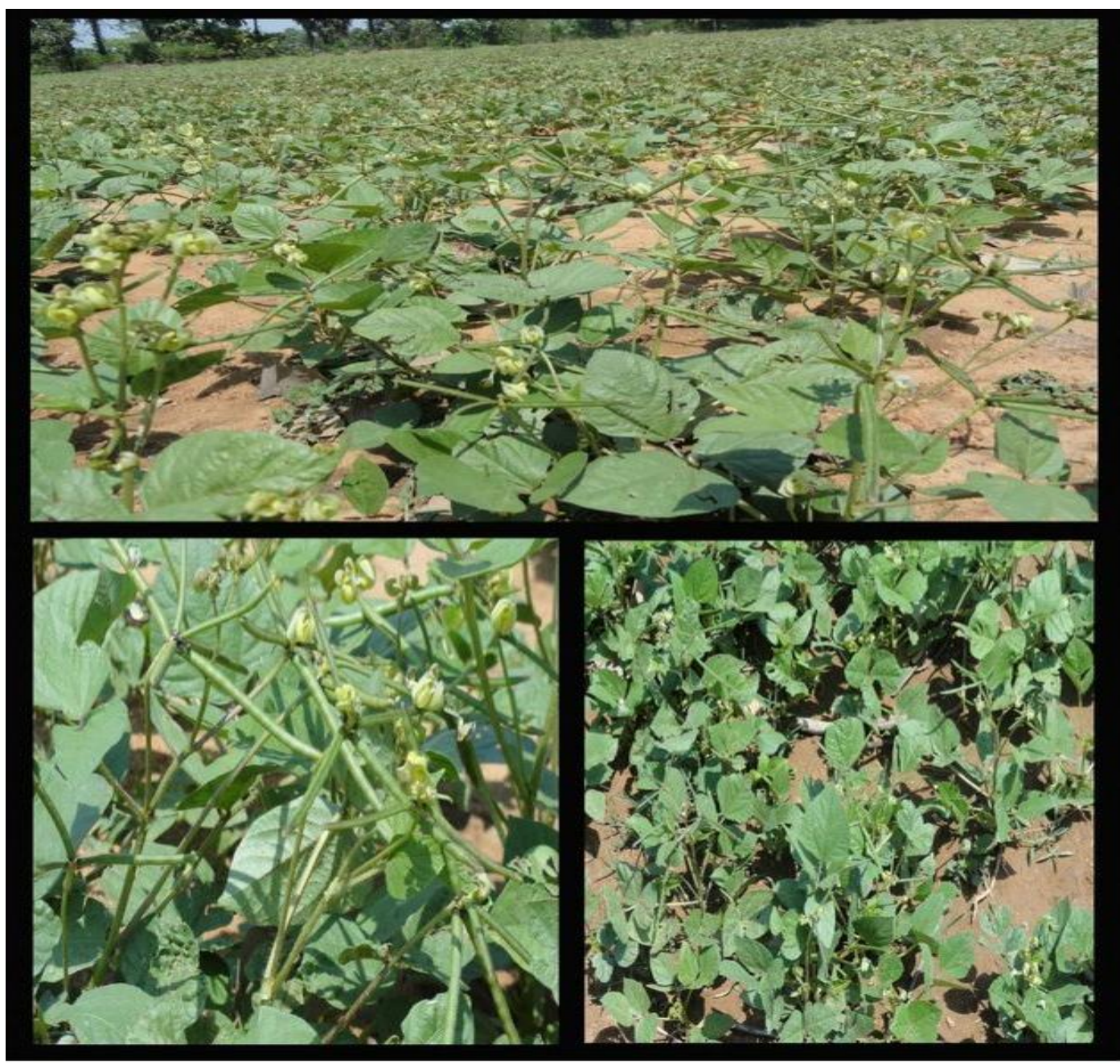


Fig.2 Response of yield (Q/ha) over control in green gram

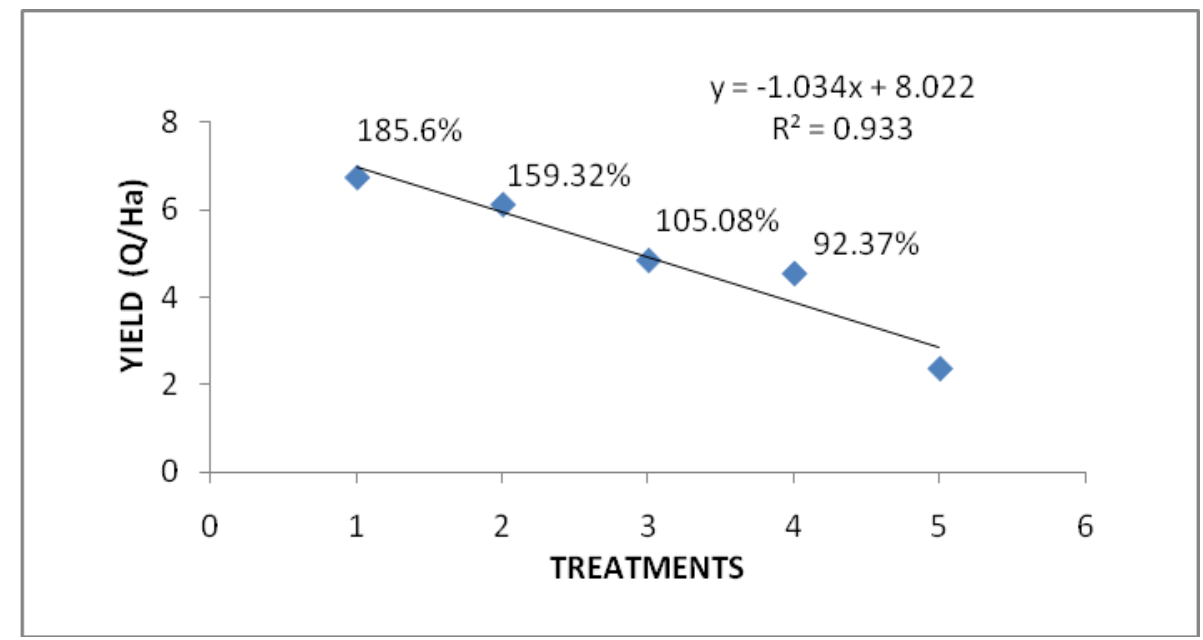

Fig.3 Response of moisture use efficiency $(\mathrm{kg} / \mathrm{ha}-\mathrm{mm})$ over control in green gram

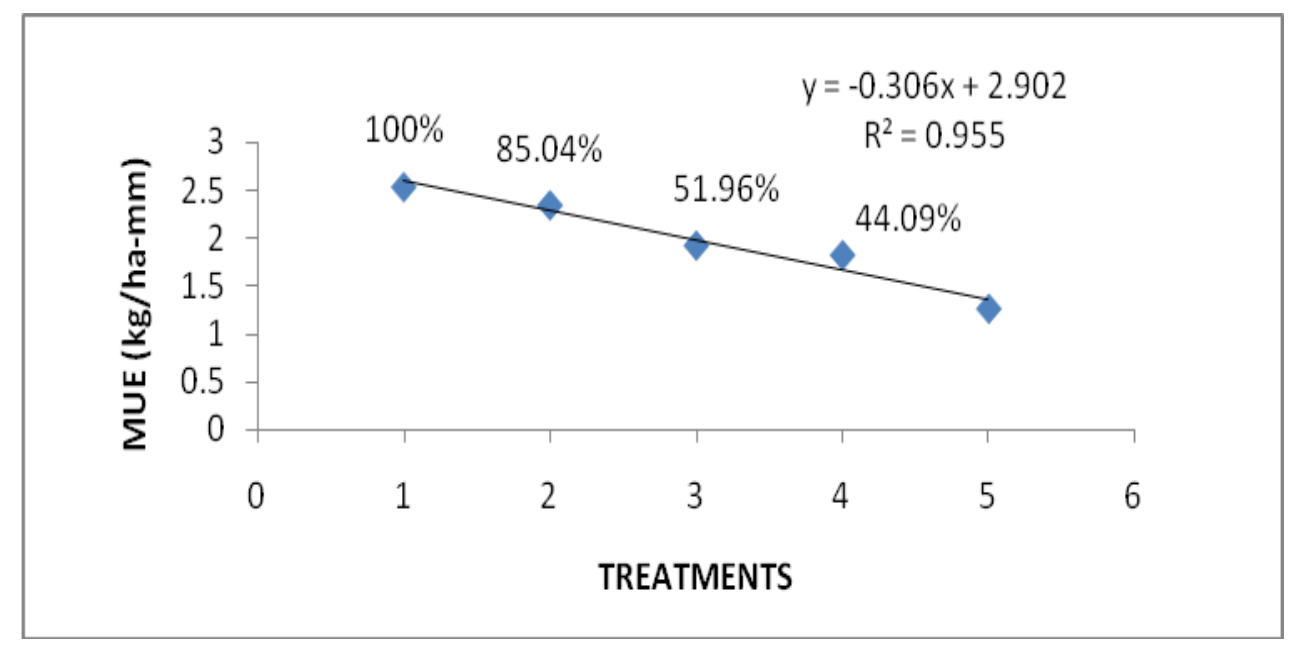

Fig.4 Relationship of yield (Q/ha) and total water use (mm)

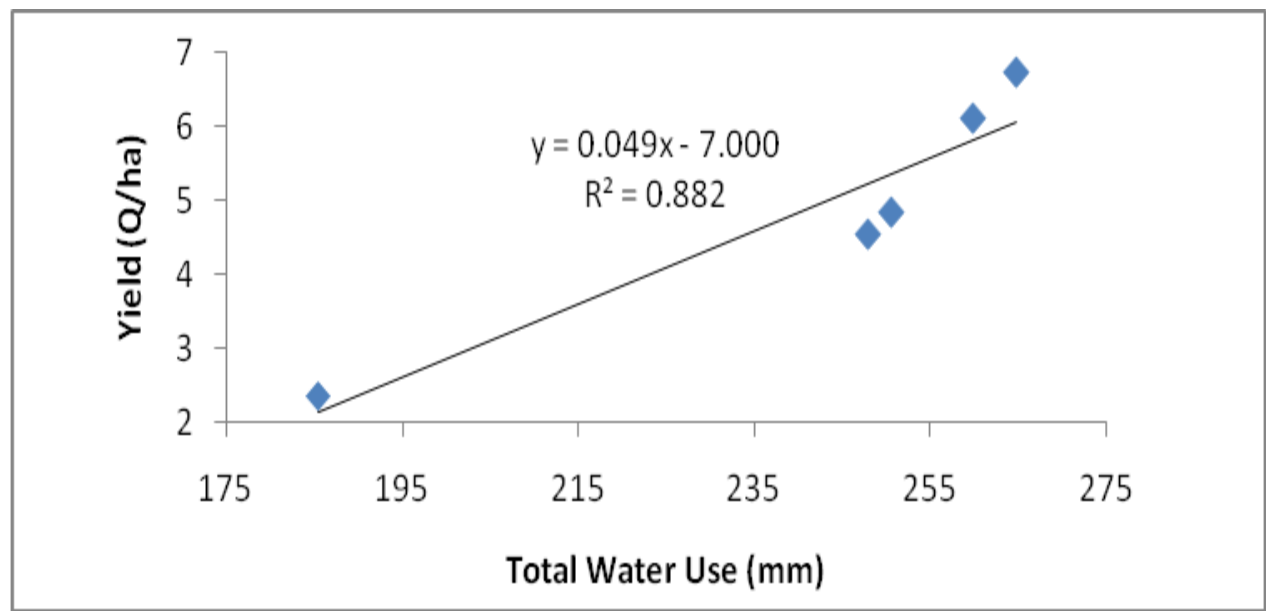


Fig.5 Effect of various jute agro textiles on changes of soil moisture pattern

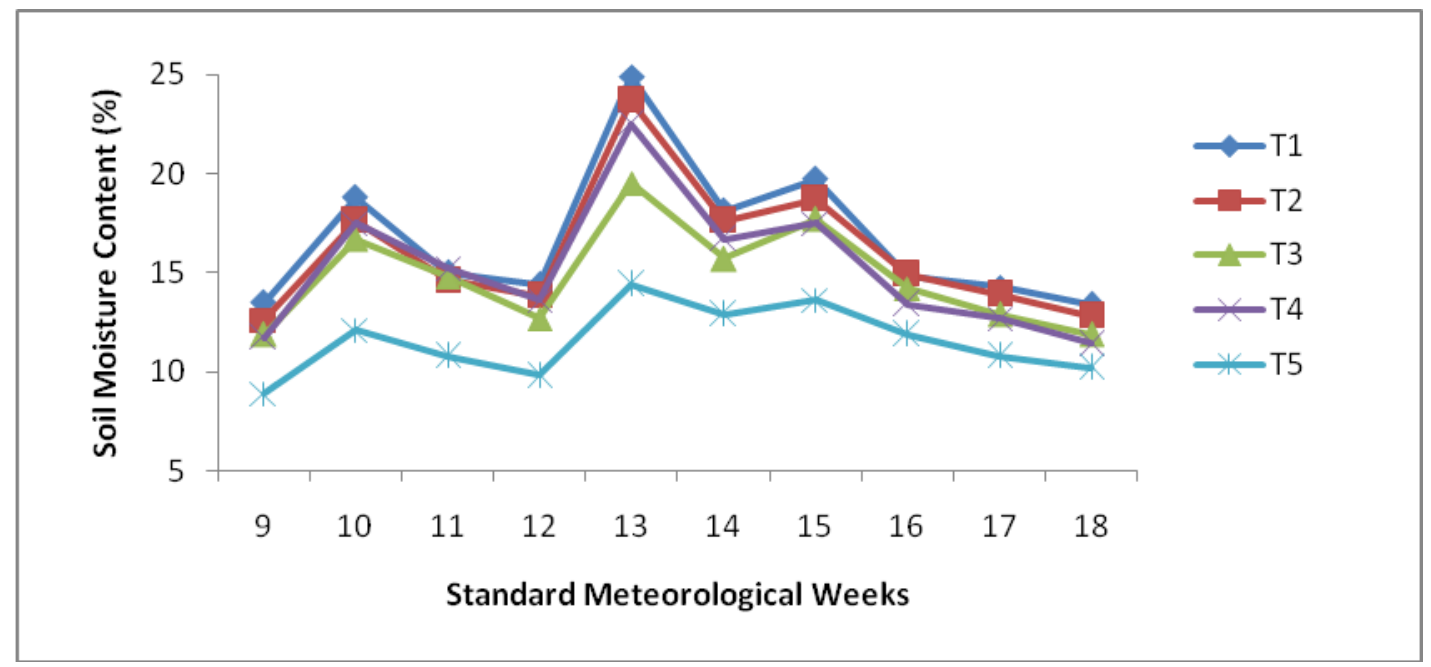

The data further showed that the moisture use efficiencies (MUE) of the crop, were increased significantly over control by 1.27 , $1.08,6.6,5.6 \mathrm{~kg} / \mathrm{ha} / \mathrm{mm}$, generally on an average, $70.27 \%$ due to the treatments of $\mathrm{T}_{1}$, $\mathrm{T}_{2}, \mathrm{~T}_{3}, \mathrm{~T}_{4}$ respectively. The highest MUE was observed in treatment 1000 GSM i.e. $100 \%$ of the control plot (Figure 3). MUE is positively and significantly correlated with no. of $\mathrm{pod} / \mathrm{plant}(\mathrm{r}=0.942)$, no. of grain/pod $(\mathrm{r}=$ $0.998), 1000$ grain weight $(r=0.896)$, crop growth rate $(\mathrm{r}=0.971)$ and grain yield $(\mathrm{r}=$ 0.996 ) at $1 \%$ level of significance (Table 4 ). The changes in soil moisture content due to various treatments might be attributed by lower bulk density and higher porosity of soil towards increasing moisture retention capacity of soil. The above results are supported by Nag et al., (2008).

The effects of various strength of jute agro textiles on yield and yield components of green gram as well as their moisture use efficiencies have investigated in the present study. All the strength of jute agro textile is proved to be more efficient than the farmer's practice for improving the production of green gram. The increase in yield was found to be the highest in case of 1000 GSM compared to 800,600 and 400 GSM, but the difference in percentage increase between 600 and $800 \mathrm{GSM}$ is greater than the percentage difference between 800 and 1000 GSM. That is, the percentage increase in yield shows a declining trend with the increase in GSM after the second treatment $T_{2}$. So, a further increase in GSM may results in an increase in yield, but with reduced magnitude leading to deceleration in net income which may not be economical considering the additional cost associated with it. JAT also improves the moisture use efficiency of the crop, hence can be used in areas of water scarcity. Acting as a mulching material, it improves the soil microenvironment i.e. optimum condition for favorable nutrient supply to the crop leading to higher productivity and income than regular condition. Thus the result leads to suggest that treatment $\mathrm{T}_{2}-800 \mathrm{GSM}$ was found to be most effective for green gram cultivation as it not only improves the quality and quantity of crop but also the moisture use pattern leading to more moisture conserving environment for sustainable and economic development in agriculture.

\section{References}

Albert, T., Karp, K., Starast, M and Paal, T. 2010. The effect of mulching and 
pruning on the vegetative growth and yield of the half-high blueberry. Agron. Res. 8: 759-769.

Anonymous (2015). Area, production and productivity of major pulse crops in Madhya Pradesh. Commissioner land records (Gwalior).

Gomez, K. A and Gomez, A. A. 1984. Statistical Procedures for Agricultural Research. 2nd Ed. Wiley, New York.

Khurshid, K., Iqbal, M., Arif, M. S and Nawaz, A. 2006. Effect of tillage and mulch on soil physical properties and growth of maize. Int. J. Agric. Biol. 8(5): 593-596.

Manna, K., Kundu, M.C., Saha, B and Ghosh, G.K. 2018. Effect of nonwoven jute agrotextile mulch on soil health and productivity of broccoli (Brassica olaracea L.) In lateritic soil. Environ. Monit. Assess. 190(82): 1-10.

Nag, D., Choudhury, T. K., Debnath, S., Ganguly, P. K and Ghosh, S. K. 2008. Efficient management of soil moisture with jute non-woven as mulch for cultivation of sweetlime and turmeric in red lateritic zone. J. Agric. Eng. 45(3): $59-62$
Paza A. 2007. The fertilization of potato with cash crops and straw. Framenta Agronomical. 24(40): 100-105.

Quilty, J. R and Cattle, S. R. 2011. Use and understanding of organic amendments in Australian agriculture: a review. Soil. Res. 49(1): 1-26.

Saha, B., Prasad, L. K., Harris, Abul. A., Sikka, A. K and Batta, R. A. 2006. Effect of geo-textile mulch on soil moisture, temperature and yield of vegetable crops grown in planes of Bihar. Int. J. Trop. Agric. 24(1-2): 153157.

Saraswati, R., Krishnamurthy, $\mathrm{R}$ and Singaram, P. 2004. Nutrient management for rain fed green gram. Madras Agric J. 91: 230-33.

Seyfi, K and Rashidi, M. 2007. Effect of drip irrigation and plastic mulch on crop yield and yield components of cantaloupe. Int. J. Agric. Biol. 9: 247249.

Taunk, J., Yadav, N.R., Yadav, R.C and Kumar, R. 2012. Genetic diversity among greengram [Vigna radiata (L) Wilczek] genotypes varying in micronutrients (Fe and $\mathrm{Zn}$ ) content using rapd markers. Ind. J. Biochem. 11 (1): $48-53$

\section{How to cite this article:}

Anwesha Sarkar, Sanjib Barui, P.K. Tarafdar and De, S.K. 2018. Jute Agro Textile as a Mulching Tool for Improving Yield of Green Gram. Int.J.Curr.Microbiol.App.Sci. 7(05): 36043611. doi: https://doi.org/10.20546/ijcmas.2018.705.416 